\title{
A Psychology of Place (Cornwall)
}

\author{
Guy Dargert, M.A.*
}

\section{University of Exeter, Peninsula College of Medicine}

\begin{abstract}
This article asks if there is a psychology or a spirit of place and, if so, how we might begin to form a contemporary understanding of a concept that has been accepted in earlier times and in cultures across the world. It cites an example of how elements of vocabulary and certain psychological issues can survive in an institutional environment despite a complete change of personnel. With specific reference to the English county of Cornwall it looks at how some typical psychological issues may arise in connection with the history, geography, and mythology of this particular place. It then cites two examples of symbolic and meaningful synchronicities that have occurred in connection with some of Cornwall's ancient monuments. It concludes that the very question of examining our relationship to place may overlook the fact that the questioners are themselves a part of the environment that they are questioning.
\end{abstract}

Is there such a thing as a psychology of place or perhaps even more provocatively a "genius loci," "spirit," or daimon of place? This is to question whether there is more than an intersubjective psychology of the people who inhabit a place. Perhaps too there is a psychology of the place itself. Certainly Jung thought so. Meredith Sabini has collected his thoughts on this topic in her book The Earth Has a Soul: C.G Jung's Writings on Nature, Technology \& Modern Life. I would like to share some thoughts on this topic based on my experience of living in a unique part of the British Isles known today as the English county of Cornwall.

$$
* * *
$$

First though, I would like say a little about myself. I have been working as a psychotherapist for the last thirty-five years; but before that I was something of a dilettante moving from job to job uncertain of my direction. I trained initially as a schoolteacher under pressure from my family who wanted me to acquire a professional qualification of some sort. To me it was more a question of delaying the evil day when I would have to decide what I was going to do in the world. I was

*Author contact: guyjas@gmail.com 
accepted in a teacher training college that proudly boasted that it was one of the most popular colleges in the country.

I recall that all of us new students were greeted in the assembly hall where we were assured by the vice principal of the college that we were "not failures." No, he reassured us, we were not at all like failures. Indeed only three percent of young people in the whole country at that time would go on to study at this advanced level. I realized then that most of my peers were people who had failed to meet the criteria to enter a "proper" university. Unlike university students we would not attain degrees but would "merely" earn ourselves teaching certificates.

Thus reassured we settled into life as young adult residential students. From then on our main contact with our family homes would be via something called the PIPs. This stood for the "People's Incoming Post." These were a set of alphabetically arranged letter boxes or "pigeon holes" near the reception desk of the college.

Twenty-five years later I returned to the college as the leader of a counsellor training course. By then the college no longer specialized in the training of teachers. My office by some strange coincidence turned out to be the room directly above the one that I had occupied as a residential student. By that time all the staff had changed. In addition to my oddly familiar office, a couple of other things had not changed. We still referred to the PIPs. However, by then no one but I knew the origin of this peculiar word. It had taken on a life of its own and survived independently of its users.

Something else also seemed to have survived the decades. The college was now in the throes of applying to upgrade itself to the status of a fully-fledged university. It faced the stiff opposition of other universities in the region who feared its competition. We were reminded by our governing staff that we were not inferior to our neighbors. No, we were just as good as the staff at accredited universities and would fight to be recognized as such. It seemed that the institutional inferiority complex was alive and well despite its change of staff.

$$
* * *
$$

If an institution can thus acquire a culture, what might be the case for a city, a region, or a nation? What psychological issues does the geographical and cultural environment draw to our attention? What is the effect on the psyche if we should deny, overlook, neglect, fail to attend to, or simply be unconscious of the psychology and spirit of the place that we inhabit? The contents of the unconscious do not cease to be. Nor do they go away. They find other indirect ways to make themselves known. They present themselves to us symbolically. This symbolism may perhaps be in the form of dreams, physical and psychological symptoms, or synchronicities.

Jungian psychologist Craig Chalquist puts it this way. 
When people inhabit a particular place, its features inhabit their psychological field, in effect becoming extended facets of their selfhood. The more they repress this local, multifaceted sense of environmental presence, the likelier its features will reappear unconsciously as symbolic, animated forces seething from within and from without. (7)

Chalquist tells of a time when he was doing a sociological study of his hometown San Diego, California. He found himself becoming inexplicably depressed. Unable to find a reason why he should be feeling this way, he attributed this puzzling and growing feeling of depression along with a sense of "caginess and guardedness" to his relationship with his partner.

An impressive dream enabled him to reframe his feelings in a way that made more sense to him. The female partner with whom he found himself in the dream was not his lover as he had expected her to be, but instead she startlingly identified herself to him as "San Diego." In the light of San Diego's geographical situation of being a border town with many illegal migrants and a major naval base his "cagey" and "guarded" feelings suddenly made a great deal more sense to him.

His further study of the "environmental presence" of the city—its "story," its history, and sociology - enabled him to relate more consciously to his location. This study enabled him better to distinguish feelings picked up in the atmosphere of San Diego from those that belonged to his human relationships. The attributes of the environmental presence of the city of which he had been unaware had presented themselves to him in a personified form in his dream.

A somewhat similar story can be told about Cornwall. Peter was a highly skilled senior medical worker in his fifties who lived in a large industrial city. He decided along with his wife to seize the opportunity to take a job in the far west of the Cornish peninsula. This region is a beautiful part of the country that is known for its rugged landscapes, picturesque fishing villages, and fine white sandy beaches that loan themselves to surfing. Here it was possible, due to lower property prices than in the city, to own a home in a quaint village with glorious views of the sea. Peter, like many other visitors, had fond memories of happy family vacations in Cornwall. His plans to realize his dream and to set up a life here drew envy from his friends in the city. However, just prior to making the move he had the following dream:

He opened a letter from the property agent. It contained a warning about the house that he and his wife were purchasing. It was apparently only a few hundred yards away from a public house called "The Spear," which was notorious as one of the most dangerous pubs in the world. It had apparently been written about 
in a famous novel. Someone had been stabbed through the heart there.

Undeterred the couple moved to their new home and their new life. However, despite the undeniable visual beauty of their new environment, Peter and his wife were soon disillusioned of their idyllic expectations of Cornwall. Peter quickly discovered that the skills he brought to his new job were not so much valued as they were resented by some of his new coworkers. His suggestions were begrudged as intrusions into the established way of doing things. Perhaps threatened by his expertise, his manager at work seemed to regard him as something of a "city slicker" who did not appreciate the established and simpler ways of the Cornish. After all, he could afford to buy a lovely home that was out of the financial reach of most of the local people who lived in this, England's poorest county.

The situation did not improve with time. He considered changing jobs, but in the rather remote, sparsely populated peninsula that is Cornwall job options were few. He increasingly came to feel unappreciated, unvalued, and marginalized. Selfdoubt arose and eroded his self-esteem and self-confidence. Meanwhile his wife, who had arrived without a prearranged job, found that she was unable to find anything other than poorly paid seasonal work. In time the dream of their new life darkened. He found more satisfying work upcountry that involved being away from home for three nights a week. His wife dealt with her growing disillusionment by becoming increasingly dependent on alcohol. In time she began an affair with another man, and the couple's dream ultimately came to a sad ending when they decided to split. During the time that these events were unfolding, Peter had the following dream. "I am standing beside a calm sea admiring its gorgeous shades of cobalt blue and turquoise. I feel charmed and seduced by its beauty. Suddenly the scene changes and I am in the sea with its waters pouring down my throat and I am unable to breathe." What he had initially experienced as beautiful and appealing had become overwhelming and life threatening.

We can see here that Peter had an intuitive apprehension of what proved to lie in store for his wife and him. Behind the beauty and charm of their seductive new location lay a dark shadow. In it lay the dangers of the public house, alcohol, and the phallic and aggressive implications of the "spear," dangers which ultimately led to him being "stabbed through the heart" by his wife's infidelity.

Cornwall is an ancient land. It is a place scattered with monuments such as stone circles and burial chambers that date back an estimated five to six thousand years. They are older than the pyramids of Egypt. In its own native language the county is called "Kernow." The name means "horn" and refers to the fact that the peninsula juts out into the Atlantic Ocean like a horn. "Cornwall" is the name given to the 
county by the later Anglo-Saxon migrants. The "wall" part of the name is a variation on the name they gave to Cymry or "Wales" to the north. It means "foreigners." So Cornwall means the land of the foreigners who live on the horn.

These "foreigners" are, of course, the earlier native inhabitants of Britain. With the advance of the Anglo-Saxons into Britain many of these native people fled the country and settled in a region of Gaul or present day France that was then known as Amorica. Today it is referred to as Brittany or "Little Britain." Here today a variation of the Cornish language is still widely spoken.

Historically speaking, Cornwall is a beleaguered nation that lost its language and many aspects of its native culture as it came under the pressure of its English neighbors. The language's last native-born speaker died in 1777, but the language had been under intense pressure since the early sixteenth century when King Henry VIII decreed that church masses should be spoken in English rather than in Latin. This directive broke the prevailing Catholic tradition and was a part of the establishment of the Church of England. However, the Cornish experienced this change as a kind of English imperialism. It meant that the Cornish would be obliged to speak the language of their eastern neighbors. Those who had not fled the country and who objected to this demand were on occasions put to death by public hanging.

Such was the case in the mid-sixteenth century with regard to a man called John Payne. According to the nineteenth century local historian William Penaluna, he was the harbor master or "portreeve" of a town called Porthia (or St. Ives) in the west of Cornwall. He was known to be an opponent of the English mass. The English Provost Marshal (a man in charge of the military police) visited the town and instructed John Payne that he have a gallows erected while they dined together. At the end of the meal the Provost Marshal announced that it would be John Payne who was hanged for the crime of being a "busy rebel" (Penaluna 17).

Arguably this history of conquest, which was followed by the violent suppression of the Cornish culture, has led to a kind of splitting in the local psyche. In my book The Snake in the Clinic I look at how this might be reflected in the stark black and white of the flag of St. Piran which has been adopted as the Cornish national emblem. The flag consists of a white cross set against a black background. I contrast this with the Taoist yin yang symbol which displays a much more nuanced understanding of the light and dark or the conscious and unconscious energies.

Today, the split seems to manifest most obviously in the tourist industry, which forms a large part of the Cornish economy. The county must necessarily put its best face forward in order to attract visitors and thereby to generate income. However, tourists, along with retirees, and second home owners who are drawn by the county's beauty, are very often unaware of its troubled history. They are thereby disconnected from a significant aspect of the psychic wholeness of the locale unless and until there 
is some kind of healing or "wholing" crisis which brings the fuller picture into consciousness.

On the surface it might appear that there is a healthy adaptive acceptance of the dominant English culture. However, occasionally anti-English graffiti appears on walls indicating that all may not be as it seems. In neighboring Wales, English owned holiday cottages have from time to time been burnt down by angry and resentful locals. Similarly the independence movements in other Celtic countries such as Ireland and Scotland attest to an underlying wish to assert the local culture. So, when we look at a case like that of Peter we might hear it with an ear to Cornish history.

Was Peter being seen as another English imperialist arriving to lay down the law without regard or sensitivity to the local culture? Was the role of oppressive outsider attributed to Peter? Were his actions so interpreted by his manager and coworkers? Indeed did Peter inadvertently and unconsciously play into these assumptions about him?

It is interesting to note that the end result of this encounter was that Peter began to feel like a beleaguered outsider. He felt disrespected, unvalued, resentful, isolated, and powerlessly angry at his reception. Together with his wife he experienced reduced financial circumstances, and in her case she turned to alcohol to escape from their shared predicament. In fact, they both began to carry and to embody some of the feelings and behaviors that are characteristic of native peoples who are dispossessed of their land and culture.

We noted earlier with Craig Chalquist's experience, that there is a danger in not recognising the possibility that an element of experience arises from the environmental psyche. It can then become displaced or misplaced, and mistakenly understood as arising solely within the personal psyche. This both inflates the importance of the individual and de-animates or de-souls the world. $* * *$

Despite the loss of its sovereignty and its occupation by the English, Cornwall maintains a sense of its unique identity. Partly perhaps as a result of its "peninsularity" things tend not to flow easily through the county. Things tend to get "stuck" or to put it more positively "preserved" in Cornwall. For instance, remnants of the old animistic pre-Christian traditions can still be found. A village called Boscastle hosts a museum which displays traditional artifacts and implements that testify to a historic and ongoing connection with the animated landscape. These include traditional Cornish dreamcatchers, which we might more usually associate with Native American tribes; bullroarers such as we generally associate with Australian aboriginal cultures; and spirit houses as are commonly seen in South East Asia. These, and the many holy wells which are believed to have healing properties, bear testimony to a belief in an animated and ensouled landscape. What are regarded by some as magical trees, grow beside these wells. These trees are still today 
commonly hung with "clouties" or pieces of cloth. Clouties that have been dipped in the healing waters of the well are believed to cure illnesses as they disintegrate. The wells have often been Christianized by the construction of a church or chapel nearby.

Also preserved is the rich folk history of Cornwall. The Cornish language was in the main not a written language. Entertainment for the Cornish often meant the telling of stories and folklore by the fire on dark winter evenings. Many of these tales were recorded in the late nineteenth century by folklorists such as William Bottrell and Robert Hunt. In the far west of Cornwall it is possible to know of stories connected with almost all of the major and many minor landmarks. The stories involve piracy, wizards, ghosts, and a great number of supernatural beings such as "spriggans" or trolls, piskies, giants, mermaids, "buccas" or hobgoblins, and "knockers" (spirits that were thought to live beneath the earth and who made knocking noises heard by the Cornish tin miners).

In parts of West Cornwall the folklore of the land is dense and rich enough that it is possible to walk through the countryside with an awareness of the mythology of place reminiscent of what we know of the Australian aboriginal "song lines." The landscape still "speaks" with the voice of its myths and legends to those who have encountered its lore. Philosopher David Abram goes so far as to suggest that preliterate people may experience a kind of synaesthesia and "hear" the stories of the land through their eyes in a comparable way to how we "hear" the voice of the written word as we gaze at a page of printed text (Spell 172).

$$
* * *
$$

A question might be whether such lore has any relevance to life today. With this in mind I would like to say something about a particular story known as "The Mermaid of Zennor." It is a story about churchgoers in the village of Zennor in the west of the county.

It seems that from time to time over a number of years a beautiful and mysterious woman would attend their church services. No one knew who she was or from where she came. She would manage to slip away from the services without getting to know any of the congregation. The people were puzzled that over the years she never seemed to get older and retained her radiant beauty. In time it became evident that she was showing some interest in a certain young man in the congregation who was known for his fine singing voice. One day he followed her from the church. Neither he nor she was ever seen again.

The story might have ended there but for the fact that some local sailors cast anchor in the nearby Pendour Cove; only then to be confronted by a mermaid who rose to the surface. She asked them to lift their anchor because it was blocking the door to her home. 
This they willingly did because they regarded the sighting of a mermaid as bad luck. When the people of Zennor heard of this they concluded that it was this mermaid who had enticed the young man to live with her beneath the sea. To commemorate these events the image of the mermaid was carved into a bench-end in the Zennor Church where it can still be seen today. (Bottrell 288-289)

What can we make of such a fanciful story? First, we must bear in mind the remarkable fact that until the nineteenth century an English law still claimed that "all mermaids found in British waters" were the property of the Crown (Holmes 228). On one level we have the story of a young man lured to his doom by the feminine principle in her inferior form as a mermaid. Although she is alluring, she is also at least half unconscious as she lives for the most part out of sight beneath the waters. Outwardly it might be a folk tale that expresses a male fear of the power of women. On a more symbolic level it might indicate the dangers of an undeveloped feeling function. A person who is out of touch with his or her feelings is in danger of being unexpectedly overwhelmed by them. In this case it is even to the point that the young man never again emerges.

Doubtless the symbolism and significance of such a tale can be profitably explored in depth and detail. However, in terms of the spirit or psychology of place we can see that the story has something to say about the seductive power of this particular geographical place. It can charm and seduce with its beauty. It can lead one to take reckless chances in order to be in its company, and it can lead to the situation of being overwhelmed and "pulled under" as was the case with Peter as, in his dream, he drowned in the very waters that had charmed him.

Is it possible that the spirit of place can hold even deeper and more mysterious energies? Are we an integral part of a continuum that stretches us beyond our physical boundaries and our rational understanding? Jung expressed it in this way.

...life is a kind of unit....it is really a continuum and meant to be as it is, namely, all one tissue in which things live through or by means of each other. Therefore trees cannot be without animals, nor animals without plants, and perhaps animals cannot be without man, and man cannot be without animals and plants-and so on. The whole thing is one tissue and so no wonder that all the parts function together, as the cells in our bodies function together, because they are of the same living continuum. (Interpretation para. 753-54 qtd. in Sabini 207).

Some people who live in Cornwall have found this to be so. Take, for example, the case of the writer Alan Bleakley who at one time lived near one of Cornwall's six thousand year old "quoits" or burial chambers. He tells of an occasion when he 
recalled a dream. He says that he was told in the dream that he should visit the quoit at four a.m. on the day of the winter solstice. He followed the instruction of his dream and headed out in the dead of night through "pelting rain" to arrive at the quoit at the appointed hour. He says that at that moment there was a "peel of thunder," and "sheet lightning lit the sky." He heard a disembodied man's voice behind him say an unfamiliar word, "Karas!" It was not until the next Easter that he again encountered the word "karas." He was at a conference where he learned that the term referred to an Egyptian method of embalming a dead body in the expectation that there would be a rebirth in the spirit world (1-2).

Bleakley had never knowingly encountered this word. As far as he was concerned, it had arisen autonomously. It was delivered in a paranormal way by a disembodied voice. Later, at the time of the Christian festival of resurrection, he learned that the word referred back to comparable rituals also concerned with death and rebirth which would doubtlessly have been relevant to the builders of the ancient quoit. If we assume that person and place are separate entities in relation to one another, we can understand that this symbolic place had stimulated a deeply significant and unconscious personal process for him. A product of this process may well have been the writing of the book in which he describes the event. However, we might also consider the possibility that the place itself has its own energy. We commonly speak of the possibility of being "drawn to a place." Maybe at some level we acknowledge that place has its own psychic energy, perhaps even its own needs and intent, which has the power to draw receptive individuals into its field.

$* * *$

In my own case I would like to tell of an experience that I had when I first took up residence in Cornwall in 2001. Before I moved to Cornwall, I had recently returned from a visit to Sri Lanka. Among the many wonderful things to be seen in that country is the cave temple complex at a town called Dambulla. Upon entry to these caves the visitor is dwarfed by one hundred and forty-three massive statues of meditating Buddhas in addition to representations of Hindu gods. The walls of the caves are embellished by over two thousand square meters of elaborate colorful gilded murals depicting scenes from the Buddhist spiritual tradition.

Arriving in Cornwall I became aware not only of the ancient burial chambers but also of a relatively newer structure that is unique to Cornwall known as a "fogou." Fogous are underground structures built by the Celtic people some two thousand years ago. Their purpose is unknown, but they generally need to be entered by crawling through a narrow opening. Inside they widen into a pitch-dark womblike space which suggests to some that they may have served a religious function, perhaps as a place of spiritual rebirth and renewal. 
In any case I was intrigued, and the Cornish landscape seemed to evoke this dream.

I am out walking in the Cornish countryside when I encounter a gap in some rocks. I go over and notice that it seems to lead into some kind of cave or fogou. I'm curious, and I crawl into the space, which opens out inside so that I am able to stand. At first it is pitch-dark, and I can see nothing at all, but as my eyes gradually become accustomed to the dark I become aware that I am surrounded by immense stone figures rather like the meditating Buddhas in the caves at Dambulla. I am amazed. I never realized that there was anything remotely like this to be found in Cornwall. I then notice that one of the "statues" moves slightly. I realize with a burst of fear and awe that these are not statues at all. They are the meditating spirits of the land. I have stumbled in amongst them and disrupted their meditation. However, the spirits don't seem to mind my being there. They talk quietly amongst themselves and seem to know that my intentions are respectful, and I am welcome to be amongst them. I then find myself lying over something like a well. A hole in the ground penetrates deep into the center of the earth. I lie over it so that my navel is over the center of the shaft. I hear the voice of what sounds like an elderly Cornish woman speaking from the earth and through my navel. She tells me that unlike her other children I am lucky to be connected with her. She says there is one thing she wants me to remember and tells me emphatically in a Cornish accent, "Whatever you do, my dear, you must not stop thinking."

I awoke with a start. I was impressed and fascinated by the dream. At the same time I was initially rather bemused by the fact that this earth goddess was reminding me of the importance of thought. If I had any preconceptions of what such a figure might say it would be that she would urge a person to be more in his or her body. Later, I understood the voice to indicate that I needed to relate to these ideas and energies from my existing standing as a psychotherapist. This and the experiences that followed seemed to indicate that my role was to act as a bridge to the cultural mainstream rather than to aspire to become a shaman.

I took the dream as a cue to actually sleep in one of the underground chambers. I chose a remote and well-preserved entrance grave on the Isles of Scilly, located some twenty-eight miles further west of the Cornish coast. It is notable that the west of Cornwall was favored by the ancients as a place to build monuments to the dead. The reason was most likely that the site was about as near to the setting sun as it is possible to be in Britain before the land gives way to what was once believed to be an endless ocean. The entrance grave was comprised of a thirty-foot grass mound that was penetrated by a stone-clad tunnel to a length of about fifteen feet. On the other side of the stones where the tunnel ended, human remains were unearthed. These were believed by some to be the remains of the tribal chieftains of those who 
had constructed the tombs. The tombs themselves are believed to date back some five thousand years.

I was fortunate to do my quest on a beautiful summer's night with the sounds of the waves slapping against the rocky shore. There were bright stars and occasional sweeping beams of light from a number of nearby lighthouses. I paid my respects and stated my intentions for my own clarity of mind and for the benefit of any other possible unseen listeners. I managed to sleep fitfully in the rather airless tomb and indeed had a dream.

It was a dream that I initially found somewhat anticlimactic. Yet, on reflection, perhaps it was deeply insightful. It was in some ways reminiscent of Jung's well known "house dream" in which he finds the remains of earlier cultures as he explores a cave below the basement and cellars of his house (Memories 155).

I am told by a voice that it is in no way special to sleep inside an ancient tomb. People who are observant will notice that every house has an ancient tomb behind it. The truth is that modern houses are extensions built onto the front of ancient tombs. I see houses that prove that this is in fact the case. I wonder ruefully how I can have overlooked such an obvious fact. The voice tells me that I have a job to do in order to unblock or unlock the vitality of earth-based spirituality.

The following day I returned home. While walking along the pavement in the town I tripped over a paving stone and nosedived onto the ground, knocking myself unconscious in the process. A passerby discovered me lying there in the street as I came back to consciousness. I was still in a kind of trance. I was unable to recall where I lived but could still remember my telephone number. I left a rather trancelike, eerie-sounding message on my answerphone while an ambulance was called to take me to the local hospital. In my attempt to break my fall I had broken a bone in my finger. When my head struck the ground I had torn the retina in one eye. I was kept in the hospital overnight for observation, and my injuries were attended to.

$* * *$

Was my accidental fall a meaningless coincidence, or was there some kind of meaningful synchronistic connection between sleeping in the chamber and the events that followed it? When we look a little more deeply into the probable use and significance of these structures, what followed on becomes meaningful. While we have no historical record of whether or how these particular tombs may have been used for ritual purposes, we do know the purpose that similar structures fulfilled in other cultures. We know, for example, that in certain South American cultures similar chambers were regarded as places where the living could meet and commune 
with ancestral spirits. In order to qualify to take on the role of such an intermediary it was considered necessary first to be contacted by the spirit world in a dream.

A priest or shaman would sometimes prepare initiates for this kind of spiritual encounter by helping them to induce a trance state in order to improve their receptivity to the voices of the spirits. In South American cultures, for example, the preparation for such an encounter with the spirits of the dead would include a period of fasting, followed by drinking copious quantities of tobacco juice or other narcotics considered to be "magical substances." In some initiations in which the dead were to be encountered, the candidate was prepared for the meeting by first being beaten unconscious by the master (Eliade 83-84).

In some shamanic traditions the breaking and reassembly of bones is regarded as an initiatory dismemberment. The break represents a ritual death, a breaking down and breaking apart of an old identity, or an old way of being. The reassembly of broken bones can represent a "new body" that is empowered and strengthened by the initiation (Eliade 429).

With regard to the eye injury we can note that in mythology a figure such as the Teutonic god Odin or Woden was obliged first to sacrifice an eye in order that he might gain the "third eye" of wisdom (Graves 261).

Alan Bleakley's experience and my own carry a distinct sense of "otherness." They appear to arise from a part of the psyche that lies well beyond the ego, or any discernible interaction with others. Here we might indeed be talking about the "genius loci" or "spirit" of place. Jung says that there is "an $x$ and a $y$ in the air and the soil of a country which slowly permeate[s] and assimilate[s]" those who live there "to the type of the aboriginal inhabitant" ( $C W 10$, par. 968).

The Cornish monuments are clearly the product of native people with a very different and more animistic way of looking at the world, at life, and at death. In the contemporary world we generally regard place merely as soulless exterior space. We neglect to consider the impact that an exterior physical place can have on the psyche of those who live there. But what if world and psyche are different aspects of the same thing? Perhaps we can agree with Jung when he says that "the earth has a soul," that "the whole thing is one tissue," and that we and the world "function together, as the cells in our bodies function together" (Interpretation qtd. in Sabini 207). Then it is not so much a question of a relationship between the two entities of self and environment. It is more about recognizing and appreciating that we are a part of a continuum. We are not separate from the environment but are a manifestation of it in the way that a wave is a manifestation of the ocean or a whirlwind is a manifestation of the air. Albert Einstein once said "A human being is a part of the whole called by us 'universe', a part limited in time and space. He experiences 
himself, his thoughts and feeling as something separated from the rest, a kind of optical delusion of his consciousness. This delusion is a kind of prison for us..." (qtd. in Calaprice 206).

We are normally unconscious of our total, inescapable immersion and participation in the world, our inextricable involvement in the being of a greater entity. We generally imagine ourselves to be creatures who live "on" the earth; whereas David Abram points out that it is actually far more accurate to recognize the fact that we are creatures who live "in" the earth. "We are enfolded within it, permeated, carnally immersed in the depths of this breathing planet" (Becoming 101).

In cases such as the tomb experiences referred to above, that greater field of which we are a part was able to make its presence felt in a way that the ego could not ignore. Maybe there is a paradox at play here. Perhaps it takes an extraordinary incident in an extraordinary place with an extraordinary history to make an impact big enough to wake us up to the spectacular ordinariness of the fact that we human beings are a manifestation of the planet. We "humans" are of the "humus" or earth. We are the "earth-born" ones, and we can therefore from time to time manifest and have direct experience of energies that stem from well beyond what we know of ourselves.

\section{Works Cited}

Abram, David. Becoming Animal: An Earthly Cosmology. Pantheon, 2010.

---. The Spell of the Sensuous: Perception and Language in a More-Than-Human World. Vintage, 1996.

Bleakley, Alan. Fruits of the Moontree: The Medicine Wheel \& Transpersonal Psychology. Gateway, 1984.

Bottrell, William. Traditions and Hearthside Stories of West Cornwall, Second Series. Llanerch, 1873 .

Calaprice, Alice. The New Quotable Einstein. Princeton UP, 1950.

Chalquist, Craig. Terrapsychology: Reengaging the Soul of Place. Spring, 2007.

Dargert, Guy. The Snake in the Clinic: Psychotherapy's Role in Medicine and Healing. Karnac, 2016.

Eliade, Mircea. Shamanism: Archaic Techniques of Ecstasy. Arkana, 1964.

Graves, Robert. Larousse Encyclopedia of Mythology. Paul Hamlyn, 1959.

Holmes, Ronald. Witchcraft in History. Citadel Press, 1974.

Hunt, Robert. (Ed.) The Drolls, Traditions, and Superstitions of Old Cornwall (Popular Romances of the West of England). Llanerch, 1993.

Jung, C. G. The Collected Works of C.G. Jung. General Editor, Sir Herbert Read et al., translated by R. F. C. Hull, 2nd ed., Princeton UP, 1953-79. 20 Vols. Bollingen Series 20.

---. Interpretation of Visions. Ed., Claire Douglass, Princeton UP, 1997. (Previously published as The Visions Seminars, Spring, 1976. 
Vol. 12, No. 1, 2017

---. Memories, Dreams, Reflections. Ed. Aniela Jaffé. Collins \& Routledge, 1963.

---. The Earth Has a Soul: The Nature Writings of C.G. Jung. Ed. Meredith Sabini. North Atlantic, 2002.

Penaluna, William. An Historical Study of the County of Cornwall, Etc., Volume 1. ReInk Books, Helston 1848. 